\title{
Understanding of flow liquefaction phenomena in Palu City from shear wave velocity profiles
}

\author{
Adrin Tohari $^{1 *}$, Imamal Muttaqien ${ }^{2}$, and Resi Wasilatus Syifa ${ }^{3}$ \\ ${ }^{1}$ Research Center for Geotechnology, National Research and Innovation Agency (BRIN), Bandung, West Java, 40135, Indonesia \\ ${ }^{2}$ Faculty of Science and Technology, State Islamic University of Sunan Gunung Djati (IUN), Bandung, West Java 40614, Indonesia \\ ${ }^{3}$ Former undergraduate student, Physics Study Program, State Islamic University of Sunan Gunung Djati (UIN), Bandung, West Java \\ 40614, Indonesia
}

\begin{abstract}
On 28 September 2018, a strong earthquake (Mw 7.5) struck Donggala Regency triggering flow liquefaction (locally termed Nalodo) phenomena in two residential areas in Palu City. Mitigating such an earthquake collateral hazard requires understanding the geological condition controlling such liquefaction. This paper presents a geophysical study to clarify the geological condition controlling the Nalodo phenomena in Palu City. The objectives of this study were to estimate shear wave velocity $\left(V_{s}\right)$ profiles in the Nalodo and non-Nalodo sites and evaluate liquefaction potential based on the shear wave velocity profiles. The study involved a series of array microtremor surveys in two Nalodo sites and three non-Nalodo sites in Palu City. The results show that $V_{s}$ generally increases with depth but varies from one site to another. Based on the $V_{s}$ profiles, a thick soil layer with $V_{s}$ of less than $175 \mathrm{~m} / \mathrm{s}$ is present from the ground surface in the Balaroa and Petobo sites. Contrary, this soil layer is detected at a deeper depth in the non-Nalodo sites. Based on the liquefaction potential analysis, the near-surface soil layers in the Balaroa and Petobo sites are clearly liquefiable for all the PGA values used in this study. Although deeper soil layers can also be liquefied, no liquefaction occurred in non-Nalodo sites because a thick medium soil layer exists near the surface. Thus, a thick soil layer with $V_{s}$ of less than $175 \mathrm{~m} / \mathrm{s}$ near the ground surface controls the Nalodo phenomena in Palu City. Further studies to clarify other factors controlling flow liquefaction are recommended.
\end{abstract}

\section{Introduction}

The 28 September 2018 strong earthquake $\left(M_{w} 7.5\right)$ triggered by the movement of the Palu-Koro Fault zone also caused massive flow liquefaction phenomena (locally termed Nalodo) in highly populated areas in the Balaroa dan Petobo sub-district in Palu City (Figure 1). The flow liquefaction phenomena have annihilated residential areas and claimed many lives in two affected areas. Since future earthquake events have still potentially triggered flow liquefaction, understanding the sub-surface condition leading to flow liquefaction is requisite to establish proper effort to mitigate such liquefaction.

According to $[1,2]$, a flow liquefaction failure commonly takes place in gently sloping areas with a slope of more than $5 \%$ and is induced by the presence of a thin sand layer below the dense soil layer [2]. However, the flow liquefaction phenomenon in Palu City only took place locally in Balaroa and Petobo areas. This discrepancy in flow liquefaction vulnerability is probably associated with the sub-surface geological condition that varies from one region to another.

The understanding of liquefaction phenomena is generally obtained from sub-surface geotechnical investigations such as geotechnical drilling with standard penetration tests $(S P T)$ and cone penetration
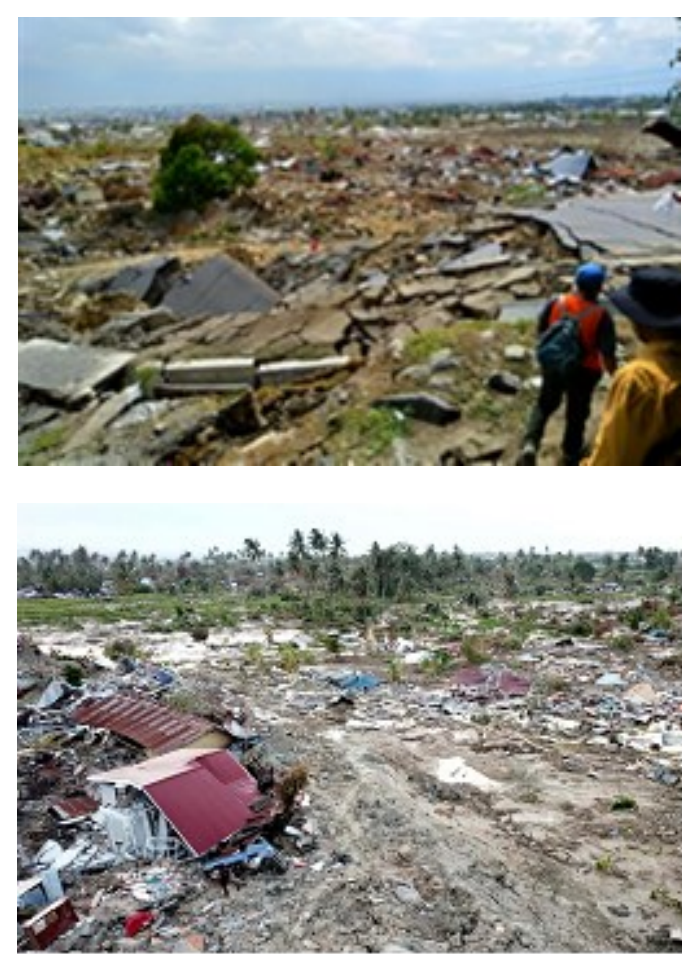

Fig. 1. Flow liquefaction disaster phenomena in Balaroa (above), and Petobo areas (below) due to the 28 September 2018 earthquake $\left(M_{w} 7.5\right)$.

* Corresponding author: adrin.tohari@gmail.com 
tests (CPT). Although these geotechnical methods provide detailed geotechnical data essential for liquefaction analysis, such as soil types, soil strength, and groundwater level, these methods are timeconsuming and costly.

Many recent studies have applied geophysical methods to study flow liquefaction phenomena in Palu City [3], [4], [5] [6]. While all these studies have provided information on the sub-surface geology and hydrological condition of the flow liquefaction areas, none has attempted to evaluate the spatial variation of sub-surface geological conditions of the flow liquefaction and no flow liquefaction areas. Thus, a geophysical study that provides a substantial understanding of the geological condition controlling flow liquefaction phenomena is favorable.

This paper presents the results of a geophysical investigation using the array microtremor method to provide an understanding of the geological condition controlling flow liquefaction phenomena in Palu City. The objectives of the study were to (1) estimate shear wave velocity $\left(V_{s}\right)$ profiles and (2) evaluate liquefaction potential based on the shear wave velocity profiles in flow liquefaction and no flow liquefaction sites.

\section{Geological condition and tectonic setting of Palu City}

\subsection{Geological condition}

According to the geomorphological classification [7], Palu City can be classified into three geomorphological classes: fluvial and structural denudational origins. The fluvial origins dominate the center part of Palu City and consist of alluvial fan, river beds, and flood plains with a slope inclination of 0 to $5 \%$. Meanwhile, the structural denudational origins consist of mainly rolling and hilly topography and hilly to mountainous ridges with a slope inclination of higher than $5 \%$. These structural denudational units extend to the north and east Palu regions. Field observations conducted after the earthquake showed that all liquefaction manifestations occurred in the fluvial geomorphological units.

Geologically, Palu City is mainly characterized by two different types of rock formations, i.e., alluvial and coastal deposits (Qap) and Celebes Molasse (QTms) [8]. The alluvial and coastal deposits are the youngest sediments in this area and are likely Holocene in age. They consist of gravel, sand, silt, and coral limestones deposited in rivers, deltas, and shallow seas.

According to [9], the alluvial deposits can be divided into young and old alluvial fan deposits, flood, alluvial, and old river channel deposits. The alluvial fan deposits are found on the hilly lowlands stretching on the east and west sides of the valley. According to Figure 2, flow liquefaction phenomena in the Balaroa and Petobo areas involved the alluvial and old alluvial fan deposits.

On the other hand, the Celebes Molasses consists of sandstones, conglomerates, mudstones, marls, and coral limestones, which are poorly consolidated and originated from older formations [8]. They are found on both ridges at lower altitudes, unconformably overlying

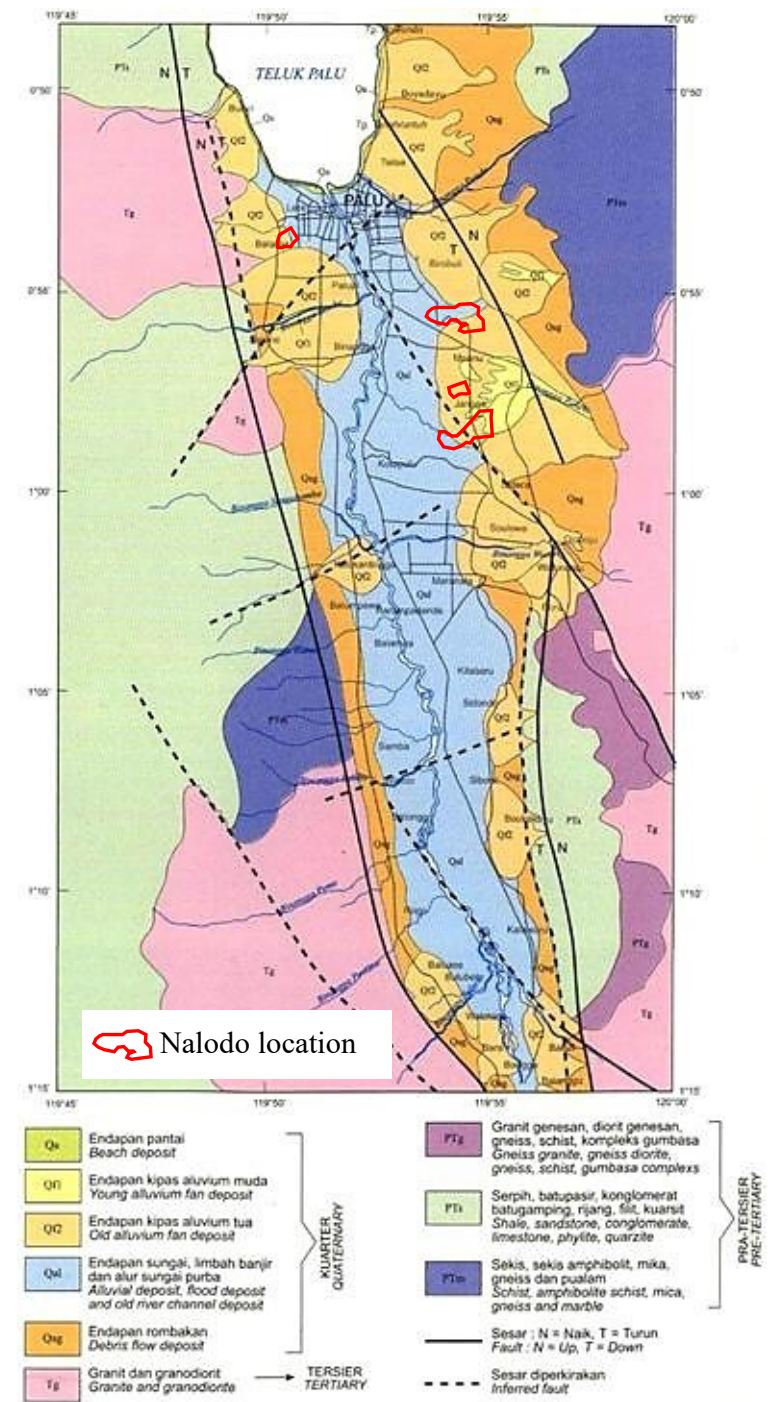

Fig. 2. The geological map of Palu City region showing the sites of flow liquefaction phenomena (modified from [7]).

the metamorphic rock complex $(\mathrm{km})$ and Tinombo Formation (Tt). Nearby the metamorphic rock complex in the western part of the eastern ridge, the molasse outcrops are made up primarily of boulders and are probably accumulated near a fault. Toward the sea, these outcrops change into fine-grained clastic rocks [8].

\subsection{Tectonic setting}

Tectonically, the geological structure in the Palu City area is primarily controlled by the main active fault, namely Palu-Koro Fault, with left-lateral movement and an NNW-SSE trend [10-14]. This strike-slip fault is recognizable within the basin, crosses the lower portion of old alluvial fans, and is characterized by the intrabasin ridge in the slightly uplifted ground surface from the adjacent surfaces [15]. The 28 September 2018 earthquake $\left(M_{w} 7.5\right)$ revealed the main Palu-Koro fault line, traceable from Sigi Regency, Palu City, and Palu Bay $[14,16]$. The fault movement yielded a maximum slip of $6 \pm 0.5 \mathrm{~m}$ within Palu City, with an average of up to $4.7 \mathrm{~m}$ in the northern and southern parts of the city [16]. 


\section{Methods}

\subsection{Microtremor data acquisition and processing}

A series of array microtremor measurements were conducted using four McSEIS MT-NEO accelerometers to estimate shear wave velocity $\left(V_{s}\right)$ profiles in 5 sites, as shown in Figure 3 and summarized in Table 1. At each site, one microtremor sensor was placed at the center of the circle with a radius, $r$. The other three were placed on the circle with the shape of a regular triangle. The measurement duration and the sampling frequency were 45 minutes and $100 \mathrm{~Hz}$, respectively. Sequential measurements were carried out five times by changing the array radius; $r=5,10,20,40$, and $80 \mathrm{~m}$.

The measurement data was transformed from the time domain into the frequency domain. Then, each dispersion curve (phase velocity vs. frequency) was calculated using the SPAC method [18]. After processing each array individually, the dispersion curve for the 5, 10, 20,40, $80 \mathrm{~m}$ arrays were combined to form a composite dispersion curve. Then, inversion analyses were undertaken on the combined dispersion curve to
Table 1. Array microtremor measurement sites.

\begin{tabular}{|c|c|c|c|}
\hline Site & \multicolumn{2}{|c|}{ Coordinates } & Remarks \\
\hline Balaroa & $0^{\circ} 54.425^{\prime} \mathrm{S}$ & $119^{\circ} 50.541^{\prime} \mathrm{E}$ & $\mathrm{F}^{*}$ \\
\hline Boyaoge & $0^{\circ} 54.895^{\prime} \mathrm{S}$ & $119^{\circ} 51.189^{\prime} \mathrm{E}$ & $\mathrm{NF}^{* *}$ \\
\hline South Tatura & $0^{\circ} 55.015^{\prime} \mathrm{S}$ & $119^{\circ} 52.492^{\prime} \mathrm{E}$ & $\mathrm{NF}^{* *}$ \\
\hline North Birobuli & $0^{\circ} 55.096^{\prime} \mathrm{S}$ & $119^{\circ} 54.044^{\prime} \mathrm{E}$ & $\mathrm{NF}^{* *}$ \\
\hline Petobo & $0^{\circ} 56.623^{\prime} \mathrm{S}$ & $119^{\circ} 54.961^{\prime} \mathrm{E}$ & $\mathrm{F}^{*}$ \\
\hline
\end{tabular}

* Flow liquefaction ** No flow liquefaction

\subsection{Liquefaction potential analysis}

Analysis of liquefaction potential with the shear wave velocity method was conducted in 3 (three) stages: (1) calculation of cyclic stress ratio (CSR), (2) calculation of cyclic resistance ratio $(C R R)$, and (3) calculation of the factor of safety against liquefaction $(F S)$.

The calculation of CSR was conducted using a simplified equation of [19] as shown in Equation 2, where $a_{\max }$ is the maximum earthquake acceleration at the ground surface $(P G A), g$ is the acceleration of gravity, $\sigma_{v}$ is the initial total vertical stress at depth $z$, $\sigma_{v}^{\prime}$ is the initial effective vertical stress, and $r_{d}$ is the

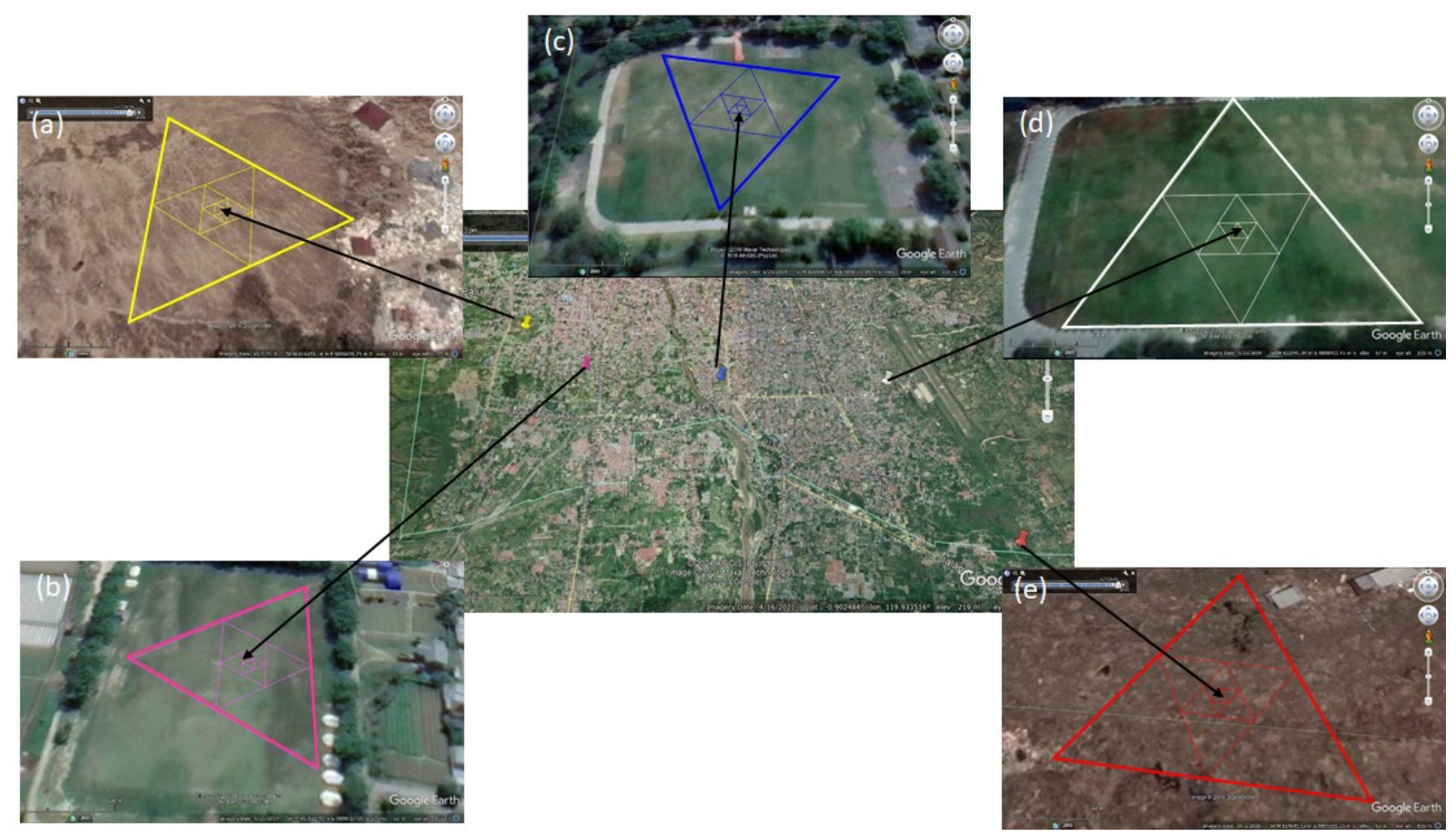

Fig. 3. Array microtremor measurement sites: (a) Balaroa, (b) Boyaoge, (c) South Tatura, (d) North Birobuli, and (e) Petobo.

estimate a shear wave velocity $\left(V_{s}\right)$ profile for each site. Then, based on the $V_{s}$ profile at each site, the average shear wave velocity to a depth of 30 meters $\left(V_{s} 30\right)$ was calculated according to Equation 1 to determine the site class.

$$
V_{S} 30=\frac{30}{\sum_{i} N_{V_{i}}}
$$

, where $N$ is the number of soil layers, $h_{i}$ is the thickness of each soil layer, and $V_{i}$ is the shear wave velocity for each soil layer. shear stress reduction factor that accounts for the dynamic response of the soil profile, according to [20].

$$
C S R=0.65 \times \frac{a_{\max }}{g} \frac{\sigma_{v}}{\sigma_{v}^{\prime}} \times r_{d}
$$

The 28 September 2018 earthquake $\left(M_{w} \quad 7.5\right)$ produced a $P G A$ of $0.34 \mathrm{~g}$, according to [21]. Meanwhile, according to [22], the $P G A$ value in all study sites is in the range of 0.4 to $0.6 \mathrm{~g}$. This current study applied $P G A$ values of 0.33 to $0.6 \mathrm{~g}$ for calculating CSR by considering the site coefficient based on the site class [22]. 
Meanwhile, the cyclic resistance ratio $(C R R)$ is calculated based on the shear wave velocity [23], as shown in Equation 3. $V_{S 1}$ is the stress-corrected shearwave velocity $(\mathrm{m} / \mathrm{s})$, and $V_{S 1}^{*}$ is the limiting upper value of $V_{S 1}$ for cyclic liquefaction occurrence, which varies between 200 and $215 \mathrm{~m} / \mathrm{s}$, depending on the fines content of the soil, and $M S F$ is a magnitude scaling factor. $V_{S l}$ is given by Equation 4 [24], where $P a$ is the reference stress of $100 \mathrm{kPa}$. The magnitude scaling factor is given by Equation 5 [25], where $M_{w}$ is the earthquake moment magnitude.

$$
\begin{gathered}
C R R=\left[0.022\left(\frac{V_{S 1}}{100}\right)^{2}+2.8\left(\frac{1}{V_{S 1}^{*}-V_{S 1}}-\frac{1}{V_{S 1}^{*}}\right)\right] M S F \\
V_{S 1}=V_{S}\left(\frac{P_{a}}{\sigma_{v}^{\prime}}\right)^{0.25} \\
M S F=\left(\frac{M_{w}}{7.5}\right)^{-2.56}
\end{gathered}
$$

Finally, the factor of safety against liquefaction $(F S)$ was determined using Equation 6 [23]:

$$
F S=C R R / C S R
$$

By convention, when $F S$ is less than 1, liquefaction is most likely to occur. On the other hand, liquefaction is unlikely to occur when $F S$ is higher and equal to 1 .

\section{Results and discussions}

\subsection{Profil $V_{s}$ and site class}

Figure 4 shows the shear wave velocity $\left(V_{s}\right)$ profile for each site obtained from the inversion process of each dispersion curve. It is evident from this figure that $V_{s}$ values generally increase with depth but vary from one
Balaroa and Petobo sites. This soil layer of less than 3 $m$ thick is also detected at depths of $2-3 \mathrm{~m}$ in the North Birobuli site. Meanwhile, the soil layer is detected deeper in the Boyaoge site than in the Balaroa and Petobo areas. It is also apparent from Figure 4 that this soil layer seems not to exist in the South Tatura site at a shallow depth. This evidence indicates that the presence of this thick soil layer of low $V_{s}$ near the ground surface is one of the controlling factors of flow liquefaction phenomena in Palu City during the 28 September 2018 earthquake. In other words, the absence of this soil layer near the ground surface will lead to no liquefaction phenomena. The results of this study are apparently in good agreement with the sub-surface geotechnical drilling data conducted by JICA [26], which show that flow liquefaction occurrence in Balaroa and Petobo areas involved loosely-packed sand, with $N-S P T$ values of less than 10 .

\subsection{Liquefaction potential}

The results of liquefaction potential analysis in all sites up to the depth of $30 \mathrm{~m}$ are shown in Figure 5. As seen in this figure, the thick soil layers of low shear wave velocity $\left(V_{s}<175 \mathrm{~m} / \mathrm{s}\right)$ in Balaroa and Petobo sites up to the depth of up to $7 \mathrm{~m}$ are liquefiable for all the prescribed PGA values. It is also worth noting that this soil layer at depths of 2-3 $\mathrm{m}$ in the North Birobuli site is also liquefiable for all the prescribed PGA values. However, only sand boiling, rather than flow liquefaction, occurred at this site during the 28 September 2018 earthquake.

As also seen in Figure 5, soil layers at deeper depths in the Boyaoge, South Tatura, and Petobo sites are also liquefiable. However, no liquefaction manifestation was observed in Boyaoge and South Tatura sites during the
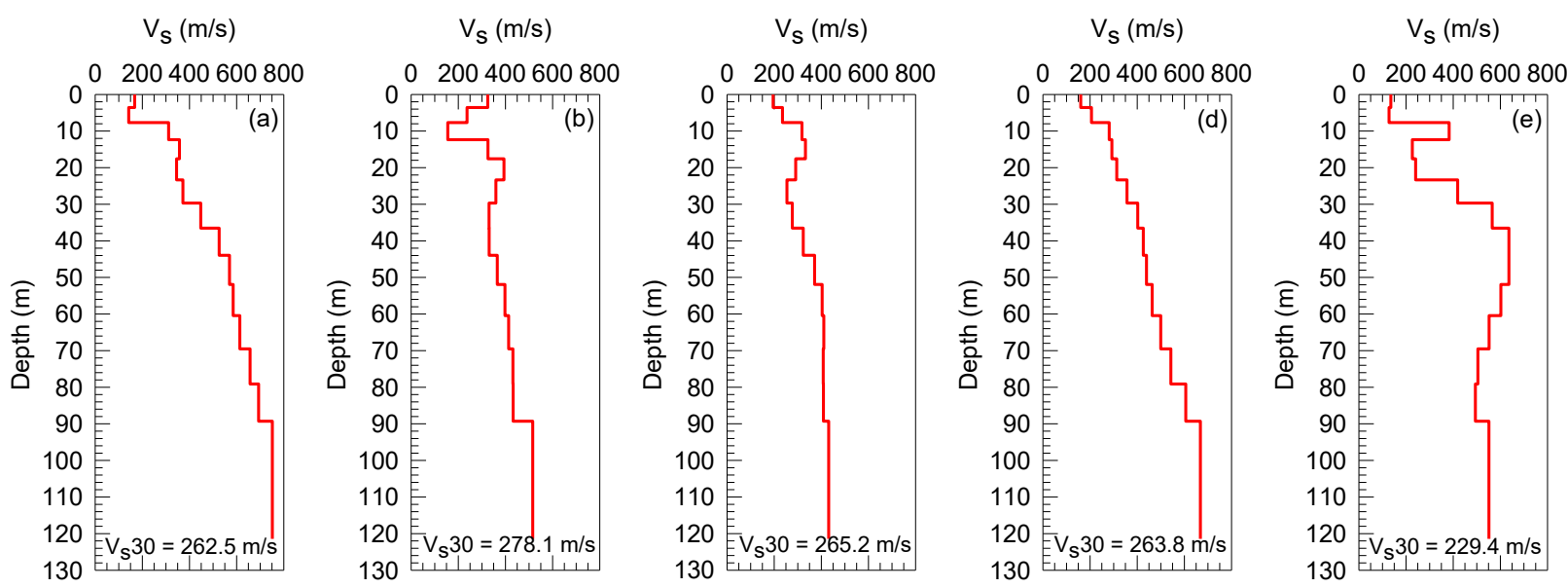

Fig. 4. Shear wave velocity profile $\left(V_{s}\right)$ for: (a) Balaroa, (b) Boyaoge, (c) South Tatura, (d) North Birobuli, and (e) Petobo sites.

site to another. For example, in the Balaroa site, the $V_{s}$ profile indicates that a bedrock layer is likely to exist from a depth of deeper than $90 \mathrm{~m}$. The bedrock layer is much deeper in other sites than the Balaroa site. According to Figure 4, all sites are classified into site class D $\left(S_{D}\right)$, with the values of $V_{s} 30$ varying between 230 and $280 \mathrm{~m} / \mathrm{s}$.

The soil layer with $V_{s}$ values of less than $175 \mathrm{~m} / \mathrm{s}$ about $7 \mathrm{~m}$ thick from the ground surface is present in the earthquake. This discrepancy is probably associated with the existence of thick, hard soil layers near the ground surface, preventing liquefaction from occurring in these two sites.

\section{Discussions}

The results of this current study point out the role of a thick, soft to medium soil layer near the ground surface 


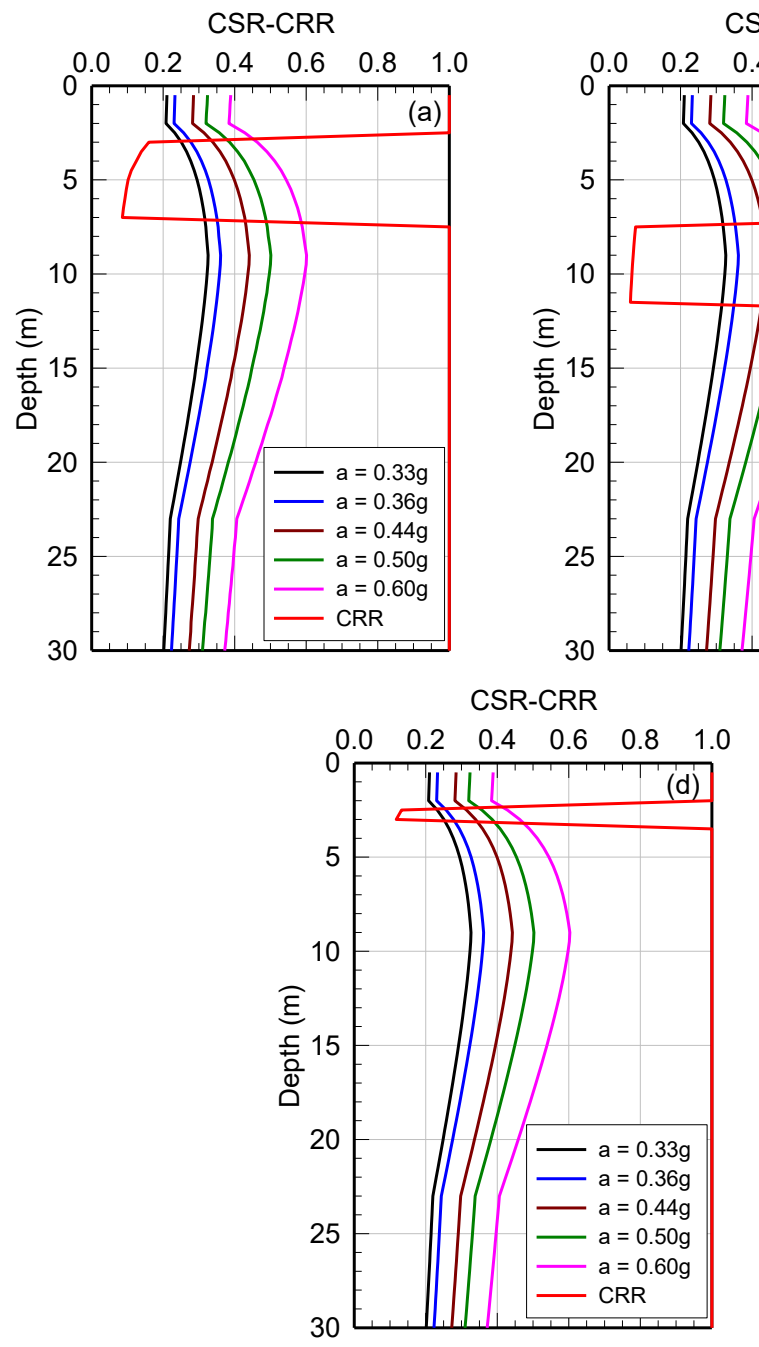

CSR-CRR

$\begin{array}{llll}0.4 & 0.6 & 0.8 & 1.0\end{array}$

(b)

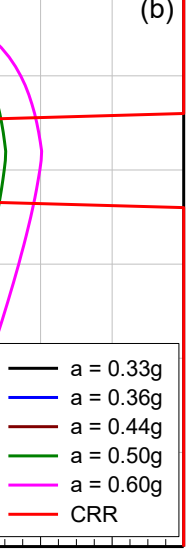

CSR-CRR

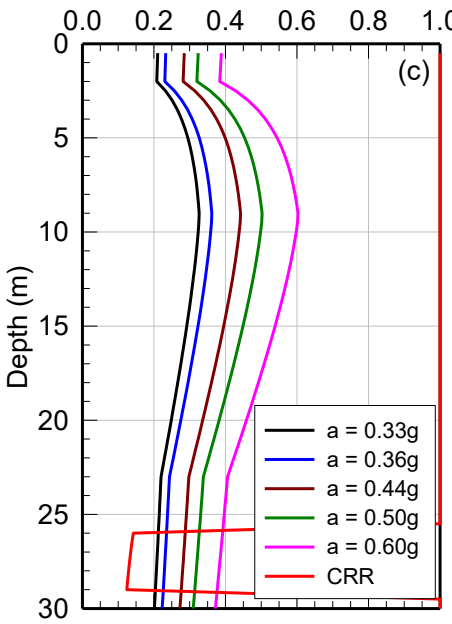

CSR-CRR

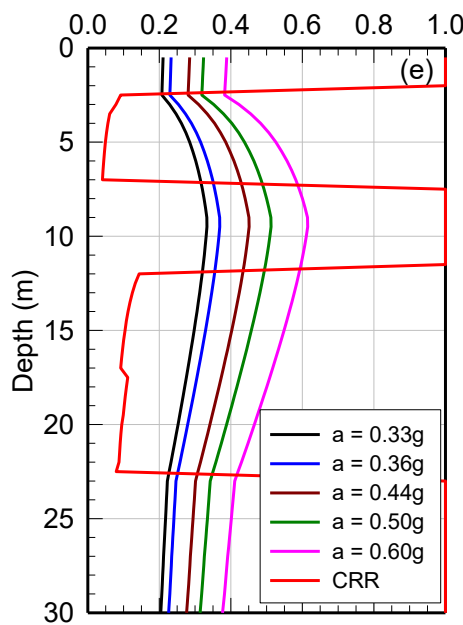

Fig. 5. Graph of CSR versus CRR for each site: (a) Balaroa, (b) Boyaoge, (c) South Tatura, (d) North Birobuli, and (e) Petobo.

as one of governing factors in the flow liquefaction occurrence in Balaroa and Petobo. However, although thick loosely-packed sediments may almost exist in Palu City, other factors may have a critical role in controlling flow liquefaction because flow liquefaction phenomena only occurred in Balaroa and Petobo areas. Based on microtremor measurements in the Balaroa, [4] found that the subsurface topographical condition in the flow liquefaction area seems to play an essential role in the occurrence of flow liquefaction at this site. Another geophysical study by [6] also indicated that the subsurface topographical conditions governed the flow liquefaction phenomena in Balaroa and Petobo areas. Thus, these studies imply the significance of a detailed subsurface study, using a combination of geophysical and geotechnical methods to establish a better understanding of subsurface geological and topographical conditions required for the potential flow liquefaction risk assessment in Palu City. Finally, massive flow liquefaction in Balaroa and Petobo may also occur in other coastal cities, built on sedimentary basins, prone to strong earthquake shaking.

\section{Conclusions}

Based on the analysis of all shear wave velocity profiles, the existence of a thick soil layer with $V_{s}$ values less than
$175 \mathrm{~m} / \mathrm{s}$ near the ground surface controls the flow liquefaction phenomena in Palu City. Although deeper soil layers may liquefy, the presence of a thick, denselypacked soil layer near the ground surface may hinder liquefaction at the ground surface. While this current study has shown how near-surface soil layers control the flow liquefaction phenomena in Palu City, further studies aiming to clarify other factors controlling flow liquefaction are recommended.

Acknowledgment. The microtremor array measurements were made possible by the 2019 INSINAS research grant from the Ministry of Research, Technology, and Higher Education. The first author would also like to thank the Japan International Cooperation Agency (JICA) for providing a microtremor equipment grant in 2017.

\section{References}

1. T.L. Youd, Civil Eng. 48, 4, 47 (1978)

2. T.L. Youd, Geologic effects-liquefaction and associated ground failure, in Proceedings of the Geologic and Hydrologic Hazards Training Program, 5-30 March 1984, Denver, Colorado (1984)

3. M. Zeffitni, M. Basir-Cyio, S. Napitupulu, Worosuprojo, J. Phys.: Conf. Series. 1434 (2020). 
4. A. Cipta, A. Rudyanto, H. Afif, R. Robiana, A. Solikhin, A. Omang, Supartoyo, S. Hidayati, Unearthing the buried Palu-Koro fault and the pattern of damage caused by the 2018 Sulawesi Earthquake using HVSR inversion in Characterization of Modern and Historical Seismic-Tsunamic Events, and Their GlobalSocietal Impacts. Editor / Y. Dilek; Y. Ogawa; Y. Okubo. Geol. Soc. London, Spec. Pub. 501(1), 185 (2021)

5. A. Yulianur, T. Saidi, B. Setiawan, Sugianto, M. Rusdi, J. Eng. Sci. Tech. 15, 5, 2871 (2020)

6. A. Tohari, D.D. Wardhana, M. Hanif, K. Koizumi, E3S Web of Conferences, 331, 03002 (2021).

7. R.A. van Zuidam, Aerial photo interpretation terrain analysis and geomorphology mapping, Smits Publisher, The Haque, Netherlands, $442 \mathrm{p}$ (1985).

8. H. Sumadirdja, T. Suptandar, S. Hardjoprawiro, D. Sudana, Reconnaissance geological map of the Palu quadrangle, Sulawesi, Pusat Penelitian dan Pengembangan Geologi, Bandung (1973)

9. A. Soehaimi, M. Firdaus., I. Effendi, Earthquake Susceptibility Zonation Map of Palu and its surrounding area, Pusat Penelitian dan Pengembangan Geologi, Bandung (2000) in Indonesian

10. J.A. Katili, Geol Rundsch. 59, 581 (1970)

11. H.D. Tjia, Bull. Geol. Soc. Malaysia 10, 73 (1978)

12. O. Bellier, M. Sébrier, D. Seward, T. Beaudouin, M. Villeneuve, E. Putranto, Tectonophys. 413, 201 (2006)

13. M.R. Daryono, Paleoseismologi Tropis Indonesia (Dengan Studi Kasus di Sesar Sumatra, Sesar Palukoro-Matano, dan Sesar Lembang). Dissertation Doctoral Program. Institut Teknologi Bandung (2016). Unpublished

14. I.M. Watkinson, R. Hall, Fault systems of the eastern Indonesian triple junction: evaluation of Quaternary activity and implications for seismic hazards Geohazards in Indonesia, in Earth Science for Disaster Risk Reduction. editor / P. Cummins; I. Meilano, Geol. Soc. London 441, 71 (2017)

15. A. Patria, P. S. Putra, Geosci. Lett. 7, 1 (2020)

16. A.I. Abdullah, Abdullah, J. Phys.: Conference Series, 1434, 012009 (2020)

17. H. Bao, J.P. Ampuero, L. Meng, E.J. Fiedling, C. Liang, C.W.D. Milliner, T. Feng, H. Huang, Nat. Geosci. 12, 200 (2019)

18. K. Aki, Bull. Earth. Res. Inst. 35, 3, 415 (1957)

19. H. B. Seed, I.M Idriss, J. Soil Mech. Found. Div., ASCE. 97(SM9), 1249 (1971).

20. S.S.C. Liao, R.V. Whitman, J. Geotech. Engrg. 112, 3, 373 (1986).

21. T. Kiyota, H. Furuichi, R.F. Hidayat, N. Tada, H. Nawir, Soils Found 60, 722 (2020)

22. Badan Standarisasi Nasional, SNI 1726:2019 (2019)
23. R.D. Andrus, K.H. Stokoe II, J. Geotech. Geoenviron. Eng., ASCE. 126(11), 1015 (2000)

24. P.K. Robertson, D.J. Woeller, W.D.L. Finn, Can. Geotech. J. 29, 4, 686 (1992)

25. T.L Youd, I.M. Idriss, R.D. Andrus, I. Arango, G. Castro, J.T. Christian, R. Dobry, W.D.L. Finn, L.F.Harder Jr., M.E. Hynes, K. Ishihara, J.P. Koester, S. S. C Liao, W.F. Marcuson III, G.R. Martin, J.K Mitchell, Y. Moriwaki, M.S. Power, P.K. Robertson, R.B. Seed, K.H. Stokoe II, J. Geotech. Geoenviron. Eng., ASCE, 127, 10, 817 (2001).

26. JICA, Project for Development of Regional Disaster Risk Resilience Plan in Central Sulawesi, Project Report (2019). 